\title{
Mercury bioaccumulation in fish of commercial importance from different trophic categories in an Amazon floodplain lake
}

\author{
Sandra Beltran-Pedreros ${ }^{1,2,3}$, Jansen Zuanon ${ }^{1}$, Rosseval Galdino Leite ${ }^{1}$, José Reinaldo \\ Pacheco Peleja ${ }^{4}$, Alessandra Barros Mendonça ${ }^{1,5}$ and Bruce Rider Forsberg ${ }^{1}$
}

\begin{abstract}
Thirty-two species of commercially important fish from three trophic levels and nine trophic categories were sampled at a floodplain lake of the Solimões River (Lago Grande de Manacapuru). The fish were analyzed to determine their Hg level and the bioaccumulation, bioconcentration, and biomagnification of this element. The observed increase in mean concentration of mercury (49.6 ng. $\mathrm{g}^{-1}$ for omnivores, $418.3 \mathrm{ng} \cdot \mathrm{g}^{-1}$ for piscivores, and $527.8 \mathrm{ng} \cdot \mathrm{g}^{-1}$ for carnivores/necrophages) furnished evidence of biomagnification. Primary, secondary, and tertiary consumers presented biomagnification factors of $0.27,0.33$, and 0.47 , respectively. Significant differences in the bioconcentration and concentration of total $\mathrm{Hg}$ occurred between the categories of the third trophic level and the other categories. Plagioscion squamosissimus (carnivorous/piscivorous) and Calophysus macropterus (carnivorous/ necrophagous) showed levels of total $\mathrm{Hg}$ above those permitted by Brazilian law (500 ng. $\left.\mathrm{g}^{-1}\right)$. Six other species also posed risks to human health because their $\mathrm{Hg}$ levels exceeded $300 \mathrm{ng} \cdot \mathrm{g}^{-1}$. Fifteen species showed bioaccumulation, but only eight presented significant correlations between the concentration of $\mathrm{Hg}$ and the length and/or the weight of the fish.

Trinta e duas espécies de peixes de importância comercial de três níveis tróficos e nove categorias tróficas foram amostradas em um lago de várzea do rio Solimões (Lago Grande de Manacapuru). Os peixes foram analisados para determinar seu nível de contaminação por mercúrio e a bioacumulação, bioconcentração e biomagnificação desse elemento. O aumento na concentração média de mercúrio (49,6 ng. $\mathrm{g}^{-1}$ para os onívoros, 418,3 ng. $\mathrm{g}^{-1}$ para os piscívoros e 527,8 ng. $\mathrm{g}^{-1}$ para os carnívoros/necrófagos) representa evidência de biomagnificação. Consumidores primários, secundários e terciários apresentaram fatores de biomagnificação de $0,27,0,33$ e 0,47 , respectivamente. Houve diferença significativa na bioconcentração e na concentração de mercúrio total entre as categorias do terceiro nível trófico e as demais. Plagioscion squamosissimus (carnívoros / piscívoros) e Calophysus macropterus (carnívoros / necrófagos) apresentaram níveis de mercúrio acima do permitido por lei (500 ng. $\left.\mathrm{g}^{-1}\right)$. Seis outras espécies também apresentam riscos para a saúde humana porque seus níveis de mercúrio ultrapassaram 300 ng.g ${ }^{-1}$. Quinze espécies apresentaram bioacumulação, mas apenas oito apresentaram correlações significativas entre a concentração de mercúrio e o tamanho e/ou o peso do peixe.
\end{abstract}

Key words: Biomagnification, Ecotoxicology, Fish quality, Floodplain, Mercury contamination.

\section{Introduction}

Mercury $(\mathrm{Hg})$ is a trace element in the biosphere and a potent neurotoxin. Its increase in the aquatic environment causes harmful effects on living organisms through bioaccumulation and biomagnification along the trophic chain. Carnivorous fish exhibit higher $\mathrm{Hg}$ levels than herbivorous and omnivorous fishes, and larger fish of the same species generally contain more $\mathrm{Hg}$ than smaller ones (Malm et al., 1997). Hg contamination diminishes the quality of fishery resources, which is especially important, because the food supply and incomes of riverside communities in

\footnotetext{
${ }^{1}$ Instituto Nacional de Pesquisas da Amazônia (INPA), Coordenação de Biodiversidade. Estrada do Aleixo, 1756, 69083-000 Manaus, AM, Brazil. beltranpedreros@hotmail.com (SBP), zuanon@inpa.gov.br(JZ), rosseval@gmail.com (RGL), alebiostm@yahoo.com.br(ABM), brforsberg@gmail.com (BRF)

${ }^{2}$ Faculdade La Salle Manaus, Coordenação de Pesquisas. Av. Dom Pedro I, 151, 69040-040 Manaus, AM, Brazil.

${ }^{3}$ Universidade Federal do Amazonas (UFAM), Programa de Pós-Graduação em Ciências Pesqueiras nos Trópicos. Av. General Rodrigo Octávio Jordão Ramos, 3000, Campus Universitário, Coroado I, 69077-000 Manaus, AM, Brazil.

${ }^{4}$ Universidade Federal do Oeste do Pará (UFOPA), Laboratório de Biologia Ambiental, Santarém. Av. Vera Paz, s/nº , 68135-110 Santarém PA, Brazil. reinaldopeleja@yahoo.com.br(JRPP)

${ }_{5}^{5}$ Instituto Nacional de Pesquisas da Amazônia (CPBA-INPA), Programa de Pós-Graduação em Biologia de Água Doce e Pesca Interior. Estrada do Aleixo, 1756, 69083-000 Manaus, AM, Brazil.
} 
Amazonia are both directly based on fishing. Thus, studies aiming at assessing the contamination levels of $\mathrm{Hg}$ are very important to public health and for the local and regional economic survival of human communities.

High levels of $\mathrm{Hg}$ have been found in different areas of the Amazon with and without a history of gold mining. Floodplains have been identified as areas of $\mathrm{Hg}$ methylation. The presence of anoxic conditions and elevated dissolved organic carbon concentrations in these areas favors the methylation process and promotes the bioaccumulation of $\mathrm{Hg}$ in aquatic fauna (Guimarães et al., 2000; Fadini \& Jardim, 2001; Bisinoti \& Jardim, 2004; Belger \& Forsberg, 2006).

Deforestation of $\mathrm{Hg}$-rich soils for agricultural activities promotes the erosive release and transport of this metal and its accumulation in the Amazon river system (Roulet et al., 1996; Malm et al., 1997; Watras et al., 1998). Podzolization also releases $\mathrm{Hg}$ from hydromorphic soils in the Amazon facilitating its export to the riverine environment (Roulet et al., 1996). Methylation of $\mathrm{Hg}$ in anoxic floodplain environments then promotes its bioaccumulation in aquatic food chains. Plankton plays a critical role in the initial transfer of $\mathrm{Hg}$ through the food chain. Planktonic organisms absorb $\mathrm{Hg}$ in the water and are then consumed by organisms at higher trophic levels (Roulet et al., 2000). Macrophytes also contribute to $\mathrm{Hg}$ transport, since the levels of methylmercury (methylHg) associated with their roots are higher than those found in the water column and in the sediment (Guimarães et al., 2000).

The different forms of $\mathrm{Hg}$ exhibit distinct and intrinsic toxicity effects in different biological systems. MethylHg is the form of most concern to human health, because is neurotoxic and teratogenic. Fish is the main source of animal protein for the inhabitants of the Amazon region and serves as a good indicator of chronic $\mathrm{Hg}$ pollution. In particular, sedentary species are good indicators of local environmental change and offer the best means for assessing the conditions of a water body (Belger \& Forsberg, 2006).

Research on $\mathrm{Hg}$ in floodplain environments is needed because of the importance of floodplains as areas of $\mathrm{Hg}$ methylation, the ease of transport of $\mathrm{Hg}$ through the trophic chain, and the increased availability of $\mathrm{Hg}$ in these ecosystems owing to land clearing for agricultural activities. The purpose of this study is to assess the levels of $\mathrm{Hg}$ and the bioaccumulation and biomagnification of this element in fish of commercial importance captured at Lago Grande de Manacapuru, a floodplain lake of the Solimões River. The results provide important information on the quality of commercial fish products consumed in the local and regional markets.

Lago Grande de Manacapuru is currently one of the biggest fishing areas on the Solimões River near Manaus, one of the main urban centers in the Amazon. Production of fish from the lake has been increasing since 1977 and amounts to 670 tons of fresh fish for local consumption and 400 tons for the national market annually. In all, $50 \%$ of the fish exported belong to the family Pimelodidae. The fishing infrastructure has also increased. The Manacapuru fishing port handles approximately 2500 tons of fish per year and generates an income of US\$ 2 million (based on the first sale) in regional, national and international markets, some located more than $3000 \mathrm{~km}$ from the lake (Batista \& Gonçalves, 2008; Sales et al., 2009).

\section{Material and Methods}

Samples were collected at Lago Grande de Manacapuru, located along the left bank of the Solimões River $\left(3^{\circ} 24^{\prime} \mathrm{S}\right.$ $60^{\circ} 50^{\prime} \mathrm{W}$ ) (Fig. 1). In this region, the water level oscillates 7-12 meters annually owing to periodic floods and droughts. The flooding period lasts from November through the end of June, and flood waters reach their highest level in July. The drying period begins in August and ends in October, when the peak of the drought occurs. As a consequence of the hydrologic cycle and the wide catchment area of the lake, the greatest water intake during the drought period is furnished by the paranás (side channels) of the innermost lakes, including Amaná and Caapiranga (clear water). When the waters are rising, the lake's inflow is supplemented by streams from terrafirme (upland) forests. Most of the water intake during the high-water period is provided by the Solimões River (white water) (A. Darwich, pers. comm.). The lake exhibits typical floodplain characteristics, with eutrophic (alluvial-gley and humic-gley) soils and plain relief around the shore, and with slight elevations characterized by red-yellow podzolic soils to the north (EMBRAPA, UFAM, SIPAM , 2007).

Monthly samples were collected from March 2007 through April 2008. Fish were sampled from open waters (the pelagic and benthonic zones), flooded forests, and aquatic macrophyte banks using gillnets (exposed for 24 hours and checked for fish every 6 hours), a bottom-trawl net (3 trawls of 5 minutes each), and seine nets. Sampling effort was standardized. After identification, measurement and weighing of the fish, we took skin and bone-free samples from the dorsal musculature $\left( \pm 3 \mathrm{~cm}^{3}\right)$ for $\mathrm{Hg}$ analyses. These samples were placed in a pressure-sealed bas and kept frozen until analysis. We also sampled surface water $(250 \mathrm{ml})$ manually using plastic bottles. The bottles had undetectable levels of $\mathrm{Hg}$ before being used for sampling.

Aquatic macrophytes were sampled by collecting the entire plant. The plants were placed in pressure-sealed plastic bags and kept on ice for transport to the laboratory. In the laboratory, we identified and washed the plant samples with Milli-Q water to remove the sediments and accompanying fauna. The roots were separated from the leaves (except for Paspalum and Echinochloa) for drying in a stove at $50^{\circ} \mathrm{C}$ for 48 hours. The samples were then ground and stored in dry plastic bottles until analysis.

$\mathrm{Hg}$ analyses were performed using 50-300 $\mathrm{mg}$ (wet weight) subsamples of the fish and 5-15 mg (dry weight) subsamples of the plants. The digestion was performed by using $1 \mathrm{ml}$ of $\mathrm{HNO}_{3}$ and $100 \mu \mathrm{l}$ of $\mathrm{HCl}(6 \mathrm{~N})$. The tubes containing the subsamples were agitated and heated at $121^{\circ} \mathrm{C}$ for 4 hours under ventilation. They were then diluted with Milli-Q to a total volume of $3 \mathrm{ml}$ (Pichet et al., 1999). Aliquots of $0.1 \mathrm{ml}$ were analyzed using a cold-vapor atomic fluorescence 


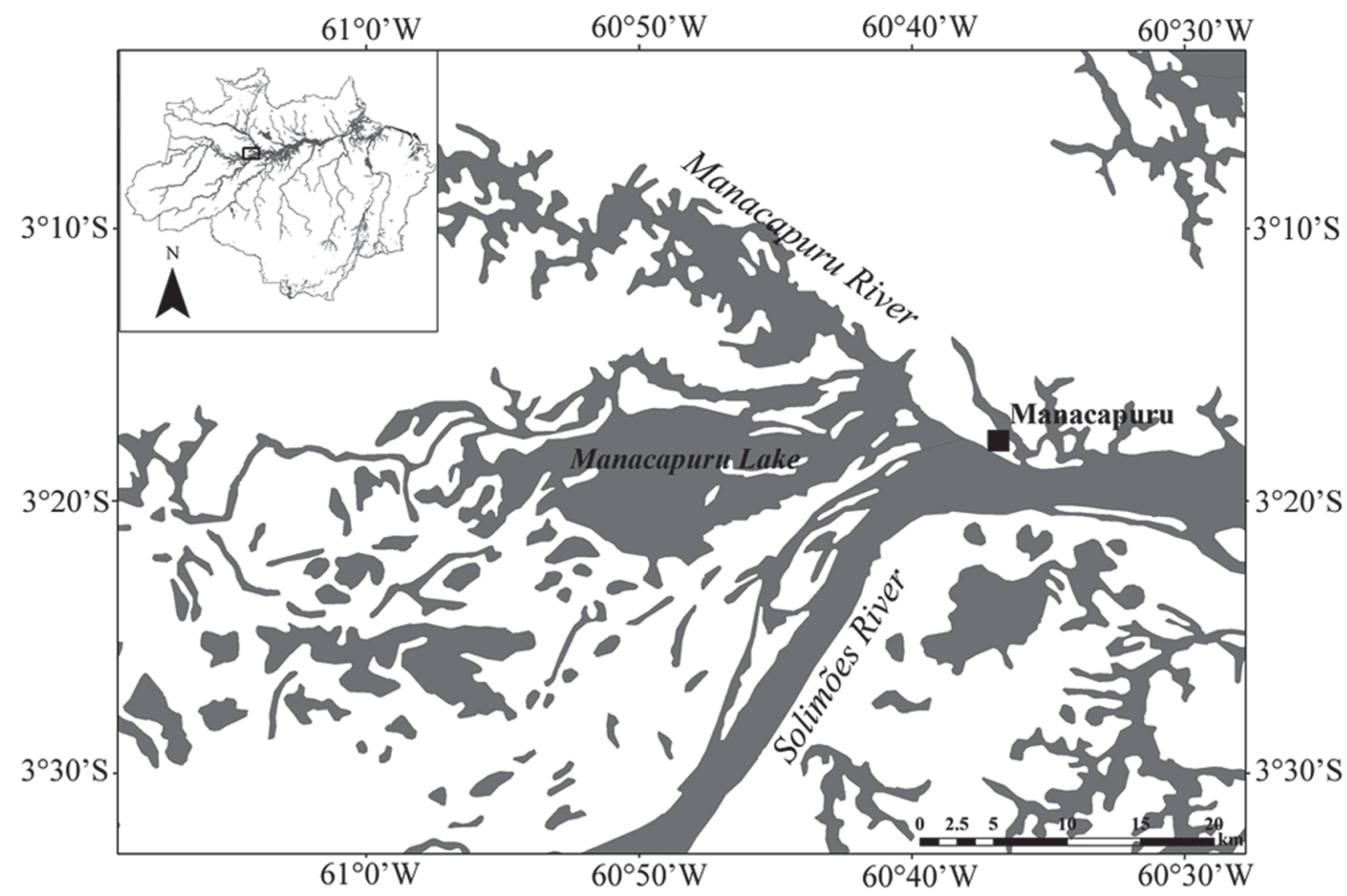

Fig. 1. Map of lago Grande de Mancapuru.

spectrophotometer. The digestion of the water samples was performed on $10 \mathrm{ml}$ of the sample with $100 \mu 1$ of $5 \%$ potassium persulfate. The prepared sample was than treated using ultraviolet oxidation in a photochemical reactor for $30 \mathrm{~min}$. Aliquots of $5 \mathrm{ml}$ were reduced with $\mathrm{SnCl}_{2}$ and analyzed in a cold-vapor atomic fluorescence spectrophotometer. The reliability of the analytical method was tested by using standard reference material from the National Research Council of Canada (TORT-2) which yielded a mean value of $289 \pm 35 \mathrm{ng} . \mathrm{g}^{-1}$ of $\mathrm{Hg}(\mathrm{n}=12)$ compared to the certified value of $270 \pm 60 \mathrm{ng} \cdot \mathrm{g}^{-1}$ of $\mathrm{Hg}$. The levels of total $\mathrm{Hg}$ in muscle were expressed as ng. $\mathrm{g}^{-1}$ (wet weight).

Bioconcentration factors ( $\mathrm{Bf}$ ) that describe how much of the $\mathrm{Hg}$ concentration in the environment is transferred to biological tissues, assuming that the equilibrium levels in the organisms have also increased, were calculated through the following equation:

$$
\mathrm{Bf}=\log (\mathrm{Cb} / \mathrm{Cw}) \text {, }
$$

where $\mathrm{Cb}$ is the level of $\mathrm{Hg}$ in the tissue samples and $\mathrm{CW}$ is the level of $\mathrm{Hg}$ in the abiotic component (water).

The biomagnification factors (Mf) that report the magnification of $\mathrm{Hg}$ from a lower trophic level to a higher level were obtained using the following formula:

$$
\mathrm{Mf}=\log \left(\mathrm{Cn} / \mathrm{Cn}^{-1}\right),
$$

where $\mathrm{Cn}$ is the level of $\mathrm{Hg}$ at a higher trophic level and $\mathrm{Cn}^{-1}$ is the level of $\mathrm{Hg}$ at the trophic level immediately below it.

The bioaccumulation pattern in fish of a given species was characterized with a simple linear regression of the $\mathrm{Hg}$ level on the standard length or the total weight of fishes. Analyses of variance were also employed to assess differences among trophic categories for the bioconcentration factor and for the total amount of $\mathrm{Hg}$.

\section{Results and Discussion}

Thirty-two species (a total of 290 specimens) out of the 50 species of commercial importance that represent $90 \%$ of the commercial fish catch in the Central Amazon region were analyzed. These species were classified into nine categories based on analyses of stomach contents: omnivores (2 species); omnivores/frugivores (1); detritivores (5); herbivores/frugivores (3); omnivores/insectivores (3); planktivores (3); carnivores/piscivores (12); piscivores (2); and carnivores/necrophages (1).

Of the species analyzed, only two exhibited levels of total $\mathrm{Hg}$ exceeding the legally accepted level: Plagioscion squamosissimus (carnivore/pisicivore) and Calophysus macropterus (carnivore/necrophage). The others fish species 
Table 1. Species organized in ascending order according to the mean concentration \pm standard deviation of total mercury $(\mathrm{Hg})$ within each trophic category in the muscle of fish of commercial importance from Lago Grande Manacapuru. n: number of samples analyzed.

\begin{tabular}{|c|c|c|c|c|c|}
\hline Trophic Category & Species & $\mathrm{Hg}_{\mathrm{ng} . \mathrm{g}^{-1}}$ & $\mathrm{n}$ & Minimum & Maximum \\
\hline & Curimata inornata & $80.89 \pm 50.31$ & 7 & 34.32 & 161.22 \\
\hline \multirow[t]{2}{*}{ Detritivore } & Prochilodus nigricans & $56.33 \pm 41.25$ & 10 & 4.69 & 171.22 \\
\hline & Semaprochilodus insignis & $63.43 \pm 32.36$ & 13 & 25.41 & 134.97 \\
\hline \multirow{3}{*}{ Herbivore/Frugivore } & Mylossoma aureum & $50.49 \pm 0.49$ & 2 & 50.00 & 50.99 \\
\hline & Mylossoma duriventre & $72.16 \pm 43.03$ & 18 & 16.11 & 140.68 \\
\hline & Piaractus brachypomus & $58.65 \pm 37.56$ & 8 & 25.18 & 140.15 \\
\hline \multirow[t]{2}{*}{ Omnivore/Frugivore } & Colossoma macropomum & $63.08 \pm 35.76$ & 12 & 39.95 & 174.41 \\
\hline & Triportheus albus & $120.94 \pm 91.84$ & 20 & 28.84 & 340.92 \\
\hline \multirow[t]{2}{*}{ Omnivore/Insectivore } & Triportheus angulatus & $152.29 \pm 67.15$ & 16 & 59.96 & 287.13 \\
\hline & Triportheus auritus & $276.45 \pm 432.70$ & 18 & 65.12 & $1,871.52$ \\
\hline \multirow[b]{2}{*}{ Planktivore } & Hypophthalmus edentatus & $275.98 \pm 159.28$ & 16 & 85.89 & 753.43 \\
\hline & Hypophthalmus fimbriatus & $179.16 \pm 101.35$ & 4 & 23.85 & 301.71 \\
\hline \multirow{8}{*}{ Carnivore/Piscivore } & Pellona flavipinnis & $327.05 \pm 251.46$ & 21 & 13.81 & $1,001.51$ \\
\hline & Pinirampus pirinampu & $363.87 \pm 19.94$ & 3 & 346.85 & 391.84 \\
\hline & Plagioscion montei & $115.00 \pm 22.14$ & 3 & 93.23 & 145.37 \\
\hline & Plagioscion squamosissimus & $547.84 \pm 228.71$ & 12 & 173.19 & 970.03 \\
\hline & Plagioscion surinamensis & $99.57 \pm 31.68$ & 4 & 46.50 & 129.57 \\
\hline & Pseudoplatystoma punctifer & 53.78 & 1 & - & - \\
\hline & Pseudoplatystoma tigrinum & $145.31 \pm 25.24$ & 2 & 120.07 & 170.55 \\
\hline & Sorubim lima & $229.09 \pm 90.23$ & 4 & 115.05 & 364.80 \\
\hline \multirow{2}{*}{ Piscivore } & Lycengraulis batesii & $406.41 \pm 264.21$ & 9 & 109.26 & 898.16 \\
\hline & Zungaro zungaro & $471.92 \pm 75.45$ & 2 & 418.57 & 525.27 \\
\hline Carnivore/Necrophagous & Calophysus macropterus & $527.82 \pm 212.67$ & 7 & 313.50 & 871.00 \\
\hline
\end{tabular}

exhibited concentrations ranging between 45.89 and 471.92 ng.g ${ }^{1}$ of wet weight (Table 1). All of these are top predators of the trophic chain and belong to three trophic categories: carnivore/ piscivore, piscivore and carnivore/necrophages.

The World Health Organization (WHO) has established 471 ng.kg body mass ${ }^{-1}$ day $^{-1}$ as the $\mathrm{Hg}$ exposure level at which no side effects would be detected in adults and $228 \mathrm{ng} . \mathrm{kg}$ body mass $^{-1}$ day $^{-1}$ for pregnant women and children (WHO/FAO, 2004). The legally established concentration limit for human consumption in Brazil is $500 \mathrm{ngHg} \cdot \mathrm{g}^{-1}$ of wet weight of food which is based on the WHO Hg ingestion limit for adults, an average body weight of $63 \mathrm{~kg}$ and an assumed food consumption rate of $60 \mathrm{~g}$.day ${ }^{-1}$. However, riverside populations in the Amazon ingest between 500 and 800 g.day $^{-1}$ of fish in the Upper Solimões River, 500-600 g.day ${ }^{-1}$ in the Central Amazon and 400 g.day $^{-1}$ in the Lower Amazon (Amazonas, 2005). In this case, the acceptable value for $\mathrm{Hg}$ in fish should be $28.8 \mathrm{ng} \cdot \mathrm{g}^{-1}$.

In the Amazon, $\mathrm{Hg}$ daily dose is particularly difficult to estimate due to the diversity of fish and ecosystems, as well as seasonal changes in fish availability. Furthermore, studies in this region have shown that fruit consumption influences the relation between fish consumption and $\mathrm{Hg}$ concentrations both in blood and hair, but it is not know how it affects the relationship between Hg intake and exposure (Passos et al., 2004, 2008).
The level of $28.8 \mathrm{ng} . \mathrm{g}^{-1}$ of $\mathrm{Hg}$ in fish, estimated here from the recommendations of WHO/FAO (2004), is a conservative value that would protect children and pregnant women from the harmful effects of $\mathrm{Hg}$ and represents a slightly higher ingestion rate than that suggested by WHO/FAO (2004; 23 ng. $\mathrm{kg}^{-1}$. day $\left.{ }^{-1}\right)$. However, $\mathrm{Hg}$ concentrations encountered in the species sampled here were almost all higher than this level, indicating that very few species would be appropriate for consumption and that dietary restrictions should be seriously considered, especially in the most vulnerable groups.

It is important to consider, however, that fish is the principal protein source for riverine populations and fish consumption varies depending on cultural practices and seasonal availability. Passos \& Mergler (2008) found that $\mathrm{Hg}$ intake via fish consumption varied from 0 to more than $4 \mu \mathrm{g} . \mathrm{kg}^{-1}$.day ${ }^{-1}$, greatly exceeding the recommended limit of $0.23 \mu \mathrm{g} \cdot \mathrm{kg}^{-1} \cdot \mathrm{day}^{-1}$. Considering the high nutritional quality of fish, which is rich in protein and Omega 3 , and the limited availability of alternative protein sources, programs to reduce $\mathrm{Hg}$ exposure in riverine populations should avoid recommending drastic restrictions in fish consumption. Such restrictions could result in protein deficiencies which could limit the neurological development of children, having a greater impact than the limited neurotoxicological effect of 


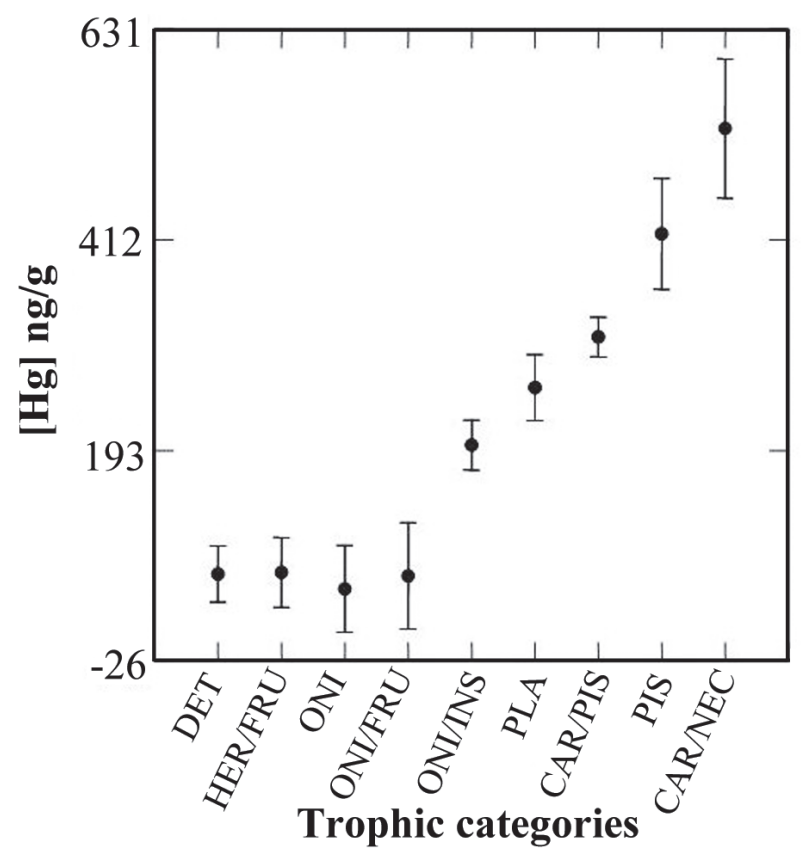

Fig. 2. Mean levels of total mercury in fish from different trophic categories in the Lago Grande de Manacapuru, in the Amazon floodplain. DET, Detritivores; HER/FRU, Herbivores/ Frugivores; ONI, Omnivores; ONI/FRU, Omnivores/ Frugivores; ONI/INS, Omnivores/Insectivores; PLA, Planktivores; CAR/PIS, Carnivores/Piscivores; PIS, Piscivores; CAR/NEC, Carnivores/Necrophagous.

$\mathrm{Hg}$ contamination. Promoting the consumption of fruits and other items in the diet could help to reduce the negative effects of $\mathrm{Hg}$ contamination without resorting to major reductions in fish consumption (Passos \& Mergler, 2008; Passos et al., 2008).

The results of this study show an overlap in the levels of total $\mathrm{Hg}$ of some species belonging to different trophic categories. This finding indicates that the concentrations of $\mathrm{Hg}$ in fish depends on other factors, such as high trophic plasticity, a characteristic of fish from the Amazon (Abelha et al., 2001) that occurs in response to variations in the abundance and availability of food resulting from the Amazon River's hydrologic cycle.

In a single species, the concentrations of total $\mathrm{Hg}$ can vary owing to differences in body size and to ontogenetic changes in feeding. This effect is reflected in the high standard deviations found in $\mathrm{Hg}$ concentration in this study (Table 1). The exposure time of immature fish to $\mathrm{Hg}$ is lower, and these fish therefore show a lower amount of bioaccumulation. Belger \& Forsberg (2006) demonstrated that Hg levels in Cichla spp. and Hoplias spp. in the Negro River basin also vary in response to several environmental variables including river $\mathrm{pH}$, dissolved organic carbon and the density of wetlands upstream of the collection point which was an indicator of potential methylation sites.
Similar results have been found for fish in north temperate streams (Chasar et al., 2009)

Analyses of isotopes of $\mathrm{C}$ and $\mathrm{N}$ in fish from the same lake point to a trophic chain with four levels (producers; primary, secondary, and tertiary consumers) but with several trophic categories (Santos, 2009). The concentrations of total $\mathrm{Hg}$ recorded in fish from different trophic categories indicated bioaccumulation (Fig. 2), as reported by Lebel et al. (1997) and Silva et al. $(2005,2007)$ for fish from the Amazon, and by Kasper et al. (2009) for fish from reservoirs in the Rio de Janeiro State, Brazil. Significant differences were found in Hg levels among categories, with a clear separation between tertiary consumers and the other trophic categories belonging to other trophic levels (ANOVA, $\mathrm{F}=14.848, \mathrm{p}=0.000, \mathrm{n}=290$ ).

The mean concentrations of total $\mathrm{Hg}$ for the different

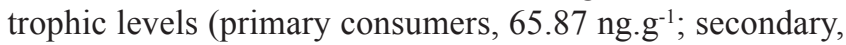

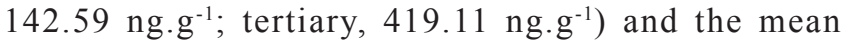
concentration of total $\mathrm{Hg}$ of 16 species of aquatic macrophytes from the lake (primary producer analyzed, $35.35 \mathrm{ng} . \mathrm{g}^{-1}$ ) were used to calculate biomagnification factors. The values of these factors were 0.27 for the second level, 0.33 for the third level, and 0.47 for the fourth level.

The bioconcentration factor for the producers analyzed $(0.73 \pm 0.17$ for aquatic macrophytes) was calculated based

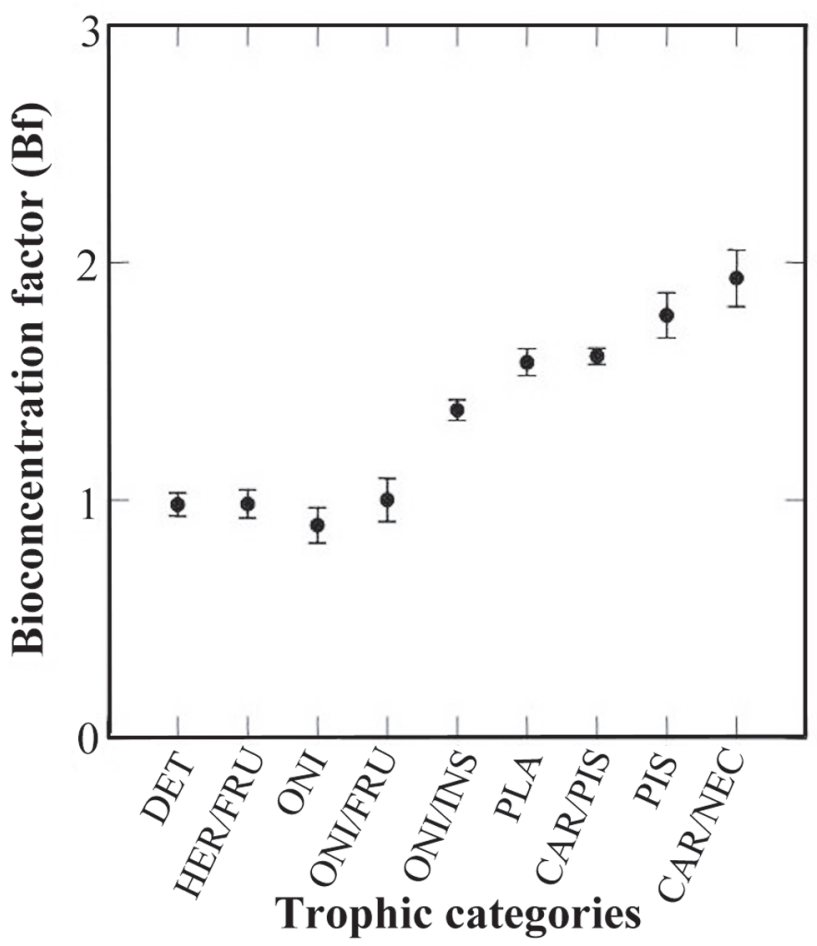

Fig. 3. Bioconcentration factor $(\mathrm{Bf})$ among trophic categories in the Lago Grande de Manacapuru, in the Amazon floodplain. DET, Detritivores; HER/FRU, Herbivores/Frugivores; ONI, Omnivores; ONI/FRU, Omnivores/Frugivores; ONI/INS, Omnivores/Insectivores; PLA, Planktivores; CAR/PIS, Carnivores/Piscivores; PIS, Piscivores; CAR/NEC, Carnivores/Necrophagous. 
Table 2. Bioaccumulation rate (B) and correlation coefficient (R) of total mercury total (ng. $\left.\mathrm{g}^{-1}\right) v s$. standard length (cm) of fish from Lago Grande de Manacapuru. ${ }^{\mathrm{S}}<0.001$. *Bioaccumulation rate for the trophic category.

\begin{tabular}{|c|c|c|c|c|}
\hline Trophic Category & Species & $\mathrm{N}$ & $\mathrm{R}$ & $\mathrm{B}$ \\
\hline \multirow{4}{*}{ Detritivore $(-1.6)^{*}$} & Curimata inornata & 7 & -0.35 & -4.91 \\
\hline & Prochilodus nigricans & 10 & -0.34 & -2.16 \\
\hline & Semaprochilodus insignis & 13 & -0.05 & -0.67 \\
\hline & Semaprochilodus taeniurus & 9 & -0.66 & -16.67 \\
\hline \multirow{2}{*}{ Herbivore/Frugivore $(-2.2)^{*}$} & Mylossoma duriventre & 18 & $-0.52^{\mathrm{s}}$ & -3.99 \\
\hline & Piaractus brachypomus & 8 & 0.56 & 13.60 \\
\hline Omnivore $(-0.06)^{*}$ & Brycon amazonicus & 14 & 0.03 & 0.19 \\
\hline Omnivore/Frugivore $(-8.9)^{*}$ & Colossoma macropoтит & 12 & -0.41 & -8.92 \\
\hline \multirow{3}{*}{ Omnivore/Insectivore (4.6)* } & Triportheus albus & 20 & -0.24 & -9.42 \\
\hline & Triportheus angulatus & 16 & -0.15 & -2.58 \\
\hline & Triportheus auritus & 18 & 0.12 & 10.25 \\
\hline \multirow{2}{*}{ Planktivore (15.6)* } & Hypophthalmus edentatus & 16 & 0.05 & 2.59 \\
\hline & Hypophthalmus marginatus & 11 & $0.80^{\mathrm{s}}$ & 51.04 \\
\hline \multirow{4}{*}{ Carnivore/Piscivore (6.9)* } & Cichla monoculus & 22 & $0.53^{\mathrm{s}}$ & 7.67 \\
\hline & Pellona castelnaeana & 9 & 0.59 & 15.46 \\
\hline & Pellona flavipinnis & 21 & 0.27 & 10.02 \\
\hline & Plagioscion squamosissimus & 12 & $0.63^{\mathrm{s}}$ & 25.80 \\
\hline $\begin{array}{l}\text { Piscivore }(3.8)^{*} \\
\end{array}$ & Lycengraulis batesii & 9 & $0.86^{\mathrm{s}}$ & 152.70 \\
\hline Carnivore/Necrophagous (52.7)* & Calophysus macropterus & 7 & $0.71^{\mathrm{s}}$ & 52.70 \\
\hline
\end{tabular}

on the mean concentration of $\mathrm{Hg}$ in water representing the abiotic component of the system $\left(5.69 \mathrm{ng} . \mathrm{l}^{-1}\right)$. Among secondary consumers, the omnivore trophic category (Brycon amazonicus and B. melanopterus) exhibited lower bioaccumulation values $(0.89 \pm 0.21)$ than those found for primary consumers, including the detritivores $(0.98 \pm 0.27$ for Curimata inornata, C. vittata, Prochilodus nigricans, Semaprochilodus insignis, and S. taeniurus) and the herbivores/frugivores $(0.98 \pm 0.28$ for Mylossoma aureum, M. duriventre, and Piaractus brachypomus). This finding could be related to the fact that species of Brycon tend to be trophic generalists that do not concentrate their foraging on one or a few food sources. Moreover, they occupy a wider variety of aquatic environments (lakes, river channels, streams) than do detritivores (basically restricted to floodplain lakes) or frugivores (found mainly in flooded forests) (Goulding, 1980; Goulding et al., 1988).

The biomagnification factors for primary consumers were calculated based on the transfer of $\mathrm{Hg}$ from aquatic macrophytes to two trophic categories of primary consumers, and resulted in almost identical values. The amplification of $\mathrm{Hg}$ from primary to secondary consumers showed negative biomagnification values for omnivores and an omnivore/ frugivore (Colossoma macropomum). These results indicated that species belonging to these trophic categories feed on resources from the forest rather than on aquatic macrophytes. The study by Oliveira (2003) regarding the isotopes of carbon and nitrogen in C. macropomum has highlighted the importance of food from the forest in the diet of this species, even during the drought period.

The concentrations of total $\mathrm{Hg}$ in water samples taken in different aquatic environments were below the maximum amount allowed by WHO $\left(10 \mathrm{ng}^{-1} \mathrm{l}^{-1}\right)$. These values were 5.07 $\pm 3.85 \mathrm{ng} . \mathrm{l}^{-1}$ for flooded forest, $5.58 \pm 3.77 \mathrm{ng} . \mathrm{l}^{-1}$ for open water, and $6.41 \pm 3.53 \mathrm{ng} .1^{-1}$ for aquatic macrophytes. The $\mathrm{Hg}$ present in the particulate material of the water column is deposited on roots, stems and leaves of aquatic macrophytes as well as on the periphyton, where it is methylated by bacteria and incorporated into the producers (Guimarães et al., 2000).

Significant differences were found for the bioconcentration factor among trophic categories (Fig. 3), with a clear separation between tertiary consumers and the trophic categories belonging to the other trophic levels (ANOVA, $\mathrm{F}=33.153, \mathrm{p}=0.000, \mathrm{n}=290$ ).

The bioaccumulation of $\mathrm{Hg}$ in fish depends on the food regime, age, size, weight, fat accumulation, metabolism, the bioavailability of $\mathrm{Hg}$, and the amount of exposure to this metal. The correlations between the levels of $\mathrm{Hg}$ and the length and weight of the fish were calculated for species with a sample size of seven or more specimens (Table 2).

We found significant relationships between fish $\mathrm{Hg}$ and size in 11 of the 19 species analyzed. Five of these species exhibited positive and significant relationships between fish $\mathrm{Hg}$ and standard length $(\mathrm{P}<0.001)$. Of the other species, only Mylossoma duriventre presented a negative significant negative relationship. This result indicates an association between the accumulation of $\mathrm{Hg}$ and size, and it suggests possible ontogenetic changes in the diet. Bioaccumulation was evident for omnivores/insectivores and accompanied the relatively frequent consumption of animal protein by these species. This result follows a pattern that has previously been described for species from the Negro River (Barbosa et al., 2003) and for marine fish (Payne \& Taylor, 2010), with the food habits and the trophic level determining the amount of bioaccumulation.

This information serves to identify species that may pose high risks to human health if consumed frequently. Calophysus macropterus is consumed national and internationally, but not regionally (in Amazonas State). 
However, Plagioscion squamosissimus and Pellona castelnaeana are widely consumed by riverside populations (Santos et al., 2006). Brachyplatystoma filamentosum and Zungaro zungaro both exhibited $\mathrm{Hg}$ levels over $350 \mathrm{ng} . \mathrm{g}^{-1}$, but only the former species showed bioaccumulation $(\mathrm{B}=423.9)$.

The observed differences in bioaccumulation may also be related to ontogenetic changes in the feeding habits. Larval fish feed on plankton and generally continue to do so until their mouth, digestive systems, and fins are fully developed, allowing the juvenile fish to explore food resources other than those found in aquatic macrophytes stands in the floodplains (Leite et al., 2002). This tendency is complemented by the processes of growth metabolism (weight, length, fat accumulation) and by migration or resistance processes (Kasper et al., 2007).

The fish of commercial importance analyzed in this study represent nine trophic categories and are structured into a 4level trophic chain - producers and primary, secondary, and tertiary consumers. The values of the bioconcentration and biomagnification factors increase along the food chain, from primary consumers to top predators.

We observed bioconcentration starting with omnivores/ insectivores and in all tertiary consumers. This result follows the pattern described for aquatic trophic chains in tropicaltemperate freshwaters and marine environments.

The results presented here indicate that most of the fish sampled have $\mathrm{Hg}$ levels above the limit recommended for safe consumption. However, detritivorous, herbivorous/ fugivorous, and omnivorous species, which are more frequently consumed by the population, are significantly lower in Hg. The consumption of predatory, planctivorous, carnivorous/piscivorous, and carnivorous/necrophagous species, which are considerably higher in $\mathrm{Hg}$, should be restricted, especially in children and pregnant women, taking care to avoiding drastic reductions which could lead to protein deficiencies.

The time of exposure to the pollutant is an important factor in the bioaccumulation of $\mathrm{Hg}$ in fish. In this regard, we may expect that large-sized species and piscivores, both sedentary and migratory, would have long exposure times and would therefore show higher levels of $\mathrm{Hg}$ than fish having short life cycles and smaller adult sizes.

\section{Acknowledgements}

We thank Conselho Nacional de Desenvolvimento Científico e Tecnológico (CNPq) for financial support through the Program BASPA (Bases para a Sustentabilidade da Pesca na Amazônia) and by the DTI scholarship to SBP; a MSc scholarship to ABM, and a productivity grant to JZ (Process \# 307464/2009-1). We also thank PETROBRAS, CPBA-INPA, UFAM and UFOPA for logistic support, FAPEAM for a doctoral scholarship granted to SBP and for financing the research (program PIPT, process \# 2864-08), and CAPES for a scholarship grant to SBP.

\section{Literature Cited}

Abelha, M. C., F. A. A. Agostinho \& E. Goulart. 2001. Plasticidade trófica em peixes de água doce. Acta Scientiarum, Biological Sciences, 23: 425-434.

Amazonas, Governo do Estado. 2005. Cadeia produtiva da pesca no Estado do Amazonas. Série Técnica Meio Ambiente e Desenvolvimento Sustentável, 7: 32.

Barbosa, A. C., J. de Souza, J. G. Dórea, W. F. Jardim \& P. S. Fadini. 2003. Mercury Biomagnification in a Tropical Black Water, Rio Negro, Brazil. Archives of Environmental Contamination and Toxicology, 45: 235-246.

Batista, V. S. \& C. Gonçalves. 2008. Avaliação do desembarque pesqueiro efetuado em Manacapuru, Amazonas, Brasil. Acta Amazonica, 38: 135-144.

Belger, L. \& B. R. Forsberg. 2006. Factors controlling Hg levels in two predatory fish species in the Negro river basin, Brazilian Amazon. Science of the Total Environment, 367: 451-459.

Bisinoti, M. C. \& W. F. Jardim. 2004. O comportamento de metilmercúrio (MetilHg) no ambiente. Química Nova, 27: 593-600.

Chasar, L. C., B. C. Scudder, A. R. Stewart, A. H. Bell \& G. R. Aiken. 2009. Mercury cycling in stream ecosystem. 3. Trophic dynamics and methylmercury Bioaccumulation. Environmental Science and Technology, 43: 2733-2739.

EMBRAPA, UFAM, SIPAM. 2007. Mapas pedológicos de municípios do meio Solimões: Área de estudos do PIATAM. Manaus, EDUA, 20p.

Fadini, P. S. \& W. F. Jardim. 2001. Is the Negro River Basin (Amazon) impacted by natural occurring mercury. The Science of the Total Environment, 275: 71-85.

Goulding, M. 1980. The fishes and forest: explorations in Amazonian natural history. Berkley, CA. USA, University of California Press, 280p.

Goulding, M., M. L. Carvalho \& E. G. Ferreira. 1988. Rio Negro: Rich life in poor water: Amazonian diversity and foodchain ecology as seen through fish communities. The Hague, SPB Academic Publishing, 200p.

Guimarães, J. R. D., M. Meili, L. D. Hylander, E. C. Silva, M. Roulet, J. B. N. Mauro \& R. A. Lemos. 2000. Mercury net methylation in five tropical floodplain regions of Brazil: high in the root zone of floating macrophyte mats but low in surface sediments and flooded soils. The Science of the Total Environment, 261: 99-107.

Kasper, D., D. Botaro, E. F. A. Palermo \& O. Malm. 2007. Mercúrio em peixes - fontes e contaminação. Oecologia Brasiliensis, 11: 228-239.

Kasper, D., E. F. A. Palermo, A. C. M. I. Dias, G. L. Ferreira, R. P. Leitão, C. W. C. Branco \& Malm, O. 2009. Mercury distribution in different tissues and trophic levels of fish from a tropical reservoir, Brazil. Neotropical Ichthyology, 7: 751-758.

Lebel, J., M. Roulet, D. Mergler, M. Lucotte \& F. Larribe. 1997. Fish diet and mercury exposure in a riparian Amazonian population. Water, Air and Soil Pollution, 97: 31-44.

Leite, R. G., C. A. R. M. Araujo-Lima, R. L. Victoria, \& L. A. Martinelli. 2002. Stable isotope analysis of energy sources for larvae of eight fish species from the Amazon floodplain. Ecology of Freshwater Fish, 11: 56-63.

Oliveira, A. C. B. 2003. Isótopos estáveis de C e N como indicadores qualitativo e quantitativo da dieta do tambaqui (Colossoma macropomum) da Amazônia central. Unpublished 
Ph.D. Dissertation, Centro de Energia Nuclear na Agricultura CENA-USP, São Paulo, 86p.

Passos, C. \& D. Mergler. 2008. Human mercury exposure and adverse health effects in the Amazon: a review. Cadernos de Saúde Pública, 24: S503-S520.

Passos, C., D. Mergler \& F. Larribe. 2004. Response to "Fruits, fish, and mercury: further considerations". Environmental Research, 96: 102-108.

Passos, C. D., S. da Silva, M. Lemire, M. Fillion, J. R.D. Guimarães, M. Lucotte \& D. Mergler. 2008. Daily mercury intake in fish-eating populations in the Brazilian Amazon. Journal of Exposure Science and Environmental Epidemiology, 18: 76-87.

Payne, E. J. \& D. L. Taylor. 2010. Effects of diet composition and trophic structure on mercury bioaccumulation in temperate flatfishes. Archives of Environmental Contamination and Toxicology, 58: 431-443.

Pichet, P., K. Morrison, I. Rheault \& A. Tremblay. 1999. Analysis of mercury and methylmercury in environmental samples. Pp. 41-52. In: Lucotte, M., R. Schetagne, N. Thérien, C. Langlois \& A. Tremblay (Eds.). Mercury in the biogeochemical cycle: Natural environments and hydroelectric reservoirs of Northern Quebec (Canada). Berlin, Springer, 334p.

Roulet, M., M. Lucotte, J. R. D. Guimarães \& I. Rheault. 2000. Methylmercury in water, seston, and epiphyton of an Amazonian rivers and floodplain, Tapajós river, Brazil. The Science of the Total Environment, 261: 43-59.
Roulet, M., M. Lucotte, R. Canuel, N. Farella, Y. G. F. Goch, J. R. P. Peleja, J. R. D. Guimarães, D. Mergler \& M. Amorim. 2001. Spatio-temporal geochemistry of mercury in waters of the Tapajós and Amazon rivers Brazil. Limnology and Oceanography, 46: 1141-1157.

Roulet, M., M. Lucotte, I. Reault, F. Tran, N. Farella, R. Canuel, D. Mergler \& M. Amorim. 1996. Mercury in Amazonian soils: accumulation and release. Proceed. IVth International Symposium on the Geochemistry of the Earth's Surface, 22-28 July 1996, Ilkley, U.K.: 453-457.

Sales, L. T. \& W. G. Cavalcanti-Filho. 2009. Informes sobre a pesca em Manacapuru, Amazonas, Brasil. Revista Brasileira de Engenharia de Pesca, 4: 1-8.

Santos, F. de A. 2009. Estrutura trófica de peixes do Lago Grande, Manacapuru, AM com base nos isótopos estáveis de C e N. Unpublished M.Sc. Dissertation, Ciências Pesqueiras nos Trópicos, UFAM, Manaus, 74p.

Santos, G. M. dos, E. J. G. Ferreira \& J. A. S. Zuanon. 2006. Peixes comerciais de Manaus. Manaus, IBAMA/AM, Pró-Várzea, 144p.

Silva, D. S. da, M. Lucotte, M. Roulet, H. Poirier, D. Mergler \& M. Crossa. 2006. Mercúrio nos peixes do rio Tapajós, Amazônia Brasileira. INTERFACEHS, 1: 1-36.

Silva, D. S. da, M. Lucotte, M. Roulet, H. Poirier, D. Mergler, E. Oliveira-Santos \& M. Crossa. 2005. Trophic structure and bioaccumulation of mercury in fish of three natural lakes of the brazilian amazon. Water, Air and Soil Pollution, 165: 77-94.

WHO/FAO. 2004. Summary and conclusions of the sixty-first meeting of the Joint FAO/WHO Expert Committee on Food Additives (JECFA), 22p.
Submitted April 14, 2011

Accepted October 5, 2011

Published December 26, 2011 